\title{
The Relationship between Corporate Social Responsibility toward the Employees and Hotel Industry Performance in Jordan
}

\author{
Marzouq Ayed Al Qeed ${ }^{1}$ \\ ${ }^{1}$ Faculty of Finance and Business, Department of Management, The World Islamic Sciences \& Education \\ University, Amman, Jordan \\ Correspondence: Marzouq Ayed Al Qeed, Faculty of Finance and Business, Department of Management, The \\ World Islamic Sciences \& Education University, PO box 1101, Amman 11947, Jordan. E-mail: \\ dr_marzouq@yahoo.com
}

Received: October 17, 2014

Accepted: December 20, 2014

Online Published: December 25, 2014

doi:10.5539/ibr.v8n1p197

URL: http://dx.doi.org/10.5539/ibr.v8n1p197

\begin{abstract}
Corporate Social Responsibility (CSR) has a positive relationship with businesses performance especially with services companies like Hotels, Hospitals and Universities. The growing concentration to Corporate Social Responsibility is based on its capability to authority company performance. The Corporate Social Responsibility movement is distribution over the world and in the current years a large number of methods and frameworks have been developed, the majority being developed in the West. The present research focuses on the relationship between Corporate Social responsibility and Jordanian Industry Hotels performance.
\end{abstract}

Methodology: A questionnaire was distributed to 100 employees in a hotels of Marriott and Movenpick where operated in Jordan Amman, Aqaba over a month in 2014, with results from Likert scales analyzed using descriptive analysis, means and SDs to tabulate and analyzed.

Results: Analysis of 83 suitable responses among the hotels employees found a significant relationship between CSR and hotels performance at the two Hypotheses.

Recommendations: Improve employee overall wages packages for employees which is based on productivity rewards. And ensure there is an equally opportunities between the employees in terms of Training.

Keywords: Corporate Social Responsibility (CSR), performance, hotels, Marriott and Movenpick, Jordan

\section{Introduction}

Tourism has considerable importance in the economic and social context of countries. It has the strongest effect on the economy, because it helps in developing other sectors (AlQeed, Bazazo, Hasoneh \& Al qaied, 2011).

The hotel industry has become one of the best industries. Jordan, focused on hotel management and workers in hotels within social responsibility (ALQeed, Alnmer Alrawey, Alqaied, and Haajdeeb, 2010) and Abedalzeez, M. (2007).

Economically Jordan would like to increase tourism investment, because of its political stability, religious toleration, a higher quality of life, better healthcare and education compared with countries in the road ( Mustafa, M.H. (2010).

Businesses ventures are primarily established to create value by introduce products and services which society demands. Corporate Social Responsibility as a concept entail the practice whereby corporate entities integrate social, environment and stakeholder in their business operations. In today business conception of corporate social responsibility imply that companies voluntarily incorporate social concerns in their operations with their stakeholders. Employees as a primary part of stakeholder. The concept of Corporate Social Responsibility is one of ethical issues surrounding corporate decision making and behavior, therefore if a firm should undertake assured activities or from doing so because they are beneficial or hurtful to society is a essential question. Social issues toward the employees deserve moral concern of their own and should lead managers to consider the social impacts of corporate activities in decision making. 


\section{Literature Review}

\subsection{CSR and Employees}

The equal opportunities for rewards and development should be provided to every employee for organization to be socially responsible. Responsible employment practices with well-trained, and motivated employees, who are adequately rewarded - sharing in the organization successes should be instituted. The organization that ignores this responsibility may probable face a risk of losing productive, highly motivated employees, Alafi, Al-Qeed and Alkayed, (2014) indicated factors affecting employee satisfaction. And They found that the overall employee dissatisfaction was $88.4 \%$ (satisfaction $11.6 \%$ ) with the highest item score for "Hospital's affected on standard of living raising of Jordanian" and lowest for "priorities and performance reporting system and the current study inconsistent with Alafi etal...(2014), but Choi and Yanni Yu,(2014) revealed in a study in China to explore the effect of CSR practices on employees" attitudes and behaviors. The authors examine the mediation impact of employees The findings showed that employees" perceptions of CSR practices have a positive effect on their organizational commitment and organizational citizenship behavior. The organizational commitment indirectly mediates the relationship only through organizational citizenship behavior, whereas organizational citizenship behavior partially mediates the relationship between CSR practices and organizational performance, and the current study conssitant with the Yanni Yu, (2014) finding a case in point being Del Monte organization should ensure that the work environment is safe, socially and should aim to be the employer of choice in all areas of operation. In Jordan, a number of laws are in place to help guide companies in aspects of employees and the workplace; examples take in the Employment Act (2010), and the Occupational Health and Safety Act (2006). For employee satisfaction in the workplace and its training, some scholars measure this factor. Both employee satisfaction and dissatisfaction are affected by the job environment and training, as well as wages( Alafi et al 2014) how much job satisfaction is possible within it (Hussami, 2008). Perceived fairness like equally opportunities in terms of Training and Promotion is a key factor affecting employee satisfaction and improved performance (Parvin \& Kabir, 2011). Nonfinancial measures also have a significant direct effect on procedural fairness (Sharon, L. C. et. al., 2012). Job satisfaction is a complex factor surrounding different facets (Alafi et al., 2014) and subject to factors like wages, (Lane, Esser, Holte \& McCusker, 2010). As a result, the success of an organization can be considerably determined and affected, together with performance and profit. The significance of studies of employee is significant for human relations and management concerning both people in companies and for the scholars seeking and analyzing relationships as well as directors and shareholders As well impacts positively on both the perception of job.

\subsection{CSR and Performance}

A business insiders, like managers seek to over invest in corporate social responsibility for their private benefits in order to develop their reputation as high-quality global citizens. There is a significant analyzed relationship between corporate social responsibility activities and performance for the period of 1996 to 2003 on 650 US companies. (Blazovich \& Smith, 2010) confirmed the relationship between corporate citizenship and performance. They also examined whether ethical corporate behavior was associated with a market-value premium. The different results indicated a significant relationship between corporate behavior and performance As a result of Study conducted by (Joshi et al., 2010) there is strongly relationship between Profit Making and Social Responsibility. Profit making is the essential reason for an enterprise to extend and grow while social responsibility is the basic duty of the "state" that must focus upon the background of its stakeholders with social justice. Showed the effect of corporate social responsibility and the organization reputation on its brand equity in business-to-business markets from the employees viewpoints on a sample of industrial purchasers in Taiwan's. The results supported their hypotheses that corporate social responsibility and corporate reputation have positive effects on industrial brand equity and brand performance. The researcher indicated that majority of the companies believe they should pay attention to corporate social responsibility however, the main barrier to adopt corporate social responsibility experienced cost and lack of human resources.

(Cyrus Iraya Mwangi, 2013) stated that the relationship between (CSR) practice and organization performance with some studies showing a positive relationship. It is with this background that this study sought to establish the relationship between corporate social responsibility practice and performance of organization listed in the manufacturing, Selvi et al., (2010) explored CSR impact on company reputation in Turkey by comparing the relationship between corporate CSR and reputation measures before and after the financial crisis.

\section{Objective of Study}

Further information about CSR and Performance will make a good contribution to the body of the Literature. Consequently the current study aims to explore and identify strategies that affect the relationship between CSR 
activities toward the employees and performance in business in general and in hotels industry in specific.

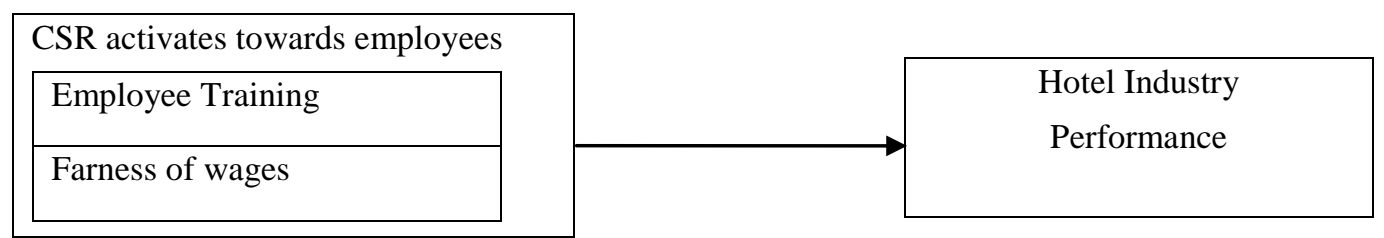

Figure 1. Research model

Source: Alafi et al., 2014

\section{Operation Definitions}

\subsection{CSR Defined}

The present study defined the CSR as an activities from the hotel industry toward employees and help them with different issues like Training, employees equally wages, working conditions.

\subsection{Hotel Industry Performance Defined}

The present study defined the performance as a hotel industry achievement in result its practice of corporate social responsibility toward its employees like Training, employees equally wages, working conditions.

\section{Hypothesis}

H.1 There is a positive relationship between CSR in terms of employees training and Hotels industry performance (Marriott, Movenpick) operating in Jordan.

H.2 There is a positive relationship between CSR in terms of employees fairness wages and Hotels industry performance (Marriott, Movenpick) operating in Jordan.

\section{Methodology}

The population of the present research covers the (Marriott, Movenpick) operating in Jordan.

Employees It is an important indication that Jordan became A number one tourist country in the Middle East and North Africa especially after the Arab spring happened in neighbors countries. Now Hotels industry play a significant role in Jordan national economic and it should be do A CSR services toward the employees to improve their quality of life in result lead to high Hotels performance. The sampling method used to collect the data is random sampling in order to avoid bias with the opinions. Samples were randomly drawn from the different level of the employees in different branches around the country( Amman, Aqaba, Dead sea, Petra and wadi mousa) 100 questionnaires were distributed to the employees 87 returned, and the researcher found 83 valid for analysis.

\subsection{Development of Questionnaires}

The questionnaires were designed to measure variables to find the relationship between the CSR and Performance. All questions are based on two hypotheses generated for the present study. The questions were designed in such a way that the participant were able to understand and answer the questions. The model of questionnaire for CSR was adapted from Alafi (2014) as it was referring to the two variables which affected its relationship on performance. The first independent variable contains items applying to the employees training. The second independent variable, fairness of employees wages, The dependent Variables measured The Hotels has a good reputation, and achieved high return on investment.

Participants were asked to indicate their awareness on the relationship between the CSR and Hotels performance. A five -point Likert scale ranging from strongly disagree (1) to strongly agree (5) was used

\section{Results}

From the Table 1 the means range was (2.87-3.77), the highest means was for the item "The hotel management is constantly preparing training programs for its employees with a mean 3.77 and STD of (0.92871) while the lowest The hotel management meets the needs of its employees continuously training" with a mean of (2.87), and STD of (0.76532) overall mean was (3.31) with STD of (06049) 
Table 1. Descriptive statistics of employees training

\begin{tabular}{|c|c|c|c|}
\hline No & Item & Mean & Standard deviation \\
\hline \multicolumn{4}{|c|}{ Employees training } \\
\hline 1. & The hotel management provide equal opportunities to its employees in term of training & 2.97 & 0.6549 \\
\hline 2 & The hotel management in the biased with some of my colleagues in terms of training & 3.64 & 0.8734 \\
\hline 3 & The hotel management is constantly preparing training programs for its employees & 3.77 & 0.92871 \\
\hline 4 & The hotel management meets the needs of its employees continuously training & 2.87 & 0.76532 \\
\hline Average & & 3.31 & 06049 \\
\hline
\end{tabular}

Table 2. Descriptive statistics of farness of wages

\begin{tabular}{llll}
\hline No & Item & Mean & Standard deviation \\
\hline Farness of wages & & & \\
5. & My payment compared to the work that I do is satisfying. & 2.90 & 0.8875 \\
6. & My pay encourages me to improve the level of quality of my work. & 3.92 & 0.9712 \\
7. & Employees that care about hotels object eves rewarded. & 2.86 & 0.6543 \\
8. & I feel a lot of loyalty to my hotel. & 3.50 & 0.5643 \\
\hline Average & & 3.295 & 0.6765 \\
\hline
\end{tabular}

From the Table 2 the means range was (2.86-3.92), the highest means was for the item "My pay encourages me to improve the level of quality of my work. with a mean 3.92 and STD of (0.9712) while the lowest Employees that care about hotels object eves rewarded with a mean of (2.86), and STD of (0.6543) overall mean was (3.295) with STD of (0.6765).

Table 3. Descriptive statistics of performance

\begin{tabular}{llll}
\hline No & Item & Mean & Standard deviation \\
\hline performance & & \\
9 & My hotel's has a good reputation & 4.30 & 0.83540 \\
10 & My hotel achieved high return on investment & 3.17 & 0.74570 \\
11. & My hotel has a market share more than the competitors & 2.85 & 0.79540 \\
12 & I feel that I am a strategic partner in my hotel & 3.46 & 0.72341 \\
13 & The hotel achieved a high annual profit & 3.20 & 0.70811 \\
\hline Average & & 3.396 & 0.78512 \\
\hline
\end{tabular}

From the Table (3) the means range was (2.85-4.30), the highest means was for the item "My hotel's has a good reputation. with a mean 4.30 and STD of (0.83540) while the lowest My hotel has a market share more than the competitors with a mean of (2.85), and STD of (0.79540) overall mean was (3.396) with STD of (0.78512)

\section{Discussion}

Employees training was also confirmed to have significant influence in Hotels industry for aspirations for higher pay, also consistent with findings by Alafi et al., 2014).

These results above may suggest that management and policy makers should seriously consider providing their employees with varied or new types of facilities as in order to give them more job satisfaction findings indicated that most employees were satisfied with the majority of factors tested in the present study: employees training which was motivator for employee satisfaction, this consistent with the prior result Parvin, Kotler, P., and Lee, N. (2005). Also the result of the present study showed a high level of the significant impact relationship between CSR and hotels performance which consistent with Research conducted by (Joshi et al., 2010) they found that 
there is strongly relationship between Profit Making and Social Responsibility.

\section{Implications for Manager}

The significant results of the present study about the relationship between CSR and performance have implications in terms of hotels management policies. From a management practice perspective, hotels need to adopt modern corporate social responsibility activities to achieve a high performance in a world increasingly demanding of CSR. This adoption of modern CSR activities should maintain or increase profitability based on the result of the present study.

\subsection{Limitations of the Study}

Generalization of data to all Jordanian Hotels employees is not possible from two hotels also may a bias of the employees considered, especially the data collected from the employees through their work at the hotels.

\subsection{Future Research}

Opportunities for future research exist in investigate other factors affecting business performance, and also the other factors of employees' satisfaction not have been taken through this study.

\subsection{Recommendations}

Foundation of the above analysis of two CSR activated toward the employees on the Hotels industry, the results suggested the following recommendations to managers of the (Marriott and Movenpick hotels) to increase performances of the Hotels Industry

1) Improve employees overall wages packages for employees which is based on productivity rewards.

2) Should the management hotel to provide equal opportunities to their employees in term of training to improve their ability make them provide a good service especially now a day's Jordan became the leader of the Region in tourist field.

3) The hotel management should take into their account the good relationships between the employees in different level of hotel management.

\section{References}

Abedazeez, M. (2007). Hotel Industry. Zahran for publication, Amman, Jordan.

AlQeed, Alnmer ,Alrawey, Alqaied, \& Haajdeeb. (2011). Principal of tourism. Athraa for publication, Amman, Jordan.

AlQeed, B. H., \& Al Qaid. (2010). Using Geographic Information System to Visualize Travel Patterns and Market Potentials of Petra City in Jordan. International Journal of Marketing Studies, 2(2).

Blazovich \& Smith. (2010). Social issues in management research: experts" views, analysis and commentary. Business and Society.

Choi \& Yanni, Y. (2014). The Influence of Perceived Corporate Sustainability Practices on Employees and Organizational Performance-china. Sustainability 2014, 6, 348-364. http://dx.doi.org/10.3390/su6010348

Creasley, K., Bryman, A., Dainty, A., Price, A., Soetanto, R., \& King, N. (2005). Employee perceptions of empowerment. Employee Relation, 27(4), 354-368. http://dx.doi.org/10.1108/01425450510605697

Cyrus, I. M. (2013). The Relationship between Corporate Social Responsibility Practices and Financial Performance of Firms in the Manufacturing, Construction and Allied Sector of the Nairobi Securities Exchange. International Journal of Business, Humanities and Technology.

Hussami, M. (2008). A Study of nurses' job satisfaction: the relationship to organizational commitment, perceived organizational support, transactional leadership, transformational leadership, and level of education. European Journal of Scientific Research; 22(2), 286-295.

Joshi, R., Sun, L., \& Mann, R. (2010). Dissecting the functional specificities of two Hoxproteins. Genes Dev., 24(14), 1533-45. http://dx.doi.org/10.1101/gad.1936910

Khaled, K. A., Marzouq, Al-Qeed., \& Waiel, A. (2014). Prevalence and Factors Affecting Employee Satisfaction: The Case of King Abdullah University Hospital in Jordan. International Journal of Business and Management, 8(23), 40-48.

Kotler, P., \& Lee, N. (2005). Corporate social responsibility: doing the most good for your company and your cause. Hoboken, New Jersey, Canada. 
Lane, K. A., Esser, J., Holte, B., \& McCusker, M. A. (2010). A study of nurse faculty job satisfaction in community colleges in Florida. Teaching Learning Nursing, 5, 16-26. http://dx.doi.org/10.1016/j.teln.2009.05.001

Mustafa, M. H. (2010). International tourism: Number of arrivals in Middle East and Arab World. International Journal of Business and Social Science, 1(1), 37-4.

Parvin, M. M., \& Kabir, M. M. N. (2011). Factors affecting employee job satisfaction of the pharmaceutical sector. Australian Journal of Business and Management Research, 1(9), 113-123.

Selvi et al. (2010). Identification of a novel inhibitor of co activator-associated argentine methyl transferees.

Sharon \& Lee. (2012). Corporate Social Responsibility in Housing Development -The Developers Perspective. Australia Journal of Applied Management Accounting Research, 10(2), 5.

\section{Copyrights}

Copyright for this article is retained by the author(s), with first publication rights granted to the journal.

This is an open-access article distributed under the terms and conditions of the Creative Commons Attribution license (http://creativecommons.org/licenses/by/3.0/). 